\title{
16. DIAGENESIS OF AMORPHOUS SILICA IN MIDDLE VALLEY, JUAN DE FUCA RIDGE ${ }^{1}$
}

\author{
C. Geoffrey Wheat ${ }^{2}$ and Jane S. Tribble ${ }^{2}$
}

\begin{abstract}
Measured profiles of dissolved and amorphous silica from the four sites (855-858) of Ocean Drilling Program Leg 139, Middle Valley, Juan de Fuca Ridge, are compared to profiles calculated from a steady-state advection-diffusion-reaction model to illustrate the effects of hydrothermal processes on diagenesis of amorphous silica. In particular, the effects of pore-water flow and the composition of basement pore water on dissolution of amorphous silica are evaluated. Based on the calculated profiles, measured profiles of dissolved and amorphous silica are interpreted in terms of past and present pore-water flow and the diagenetic transformation of amorphous silica to quartz.

Four sites were drilled, each with different patterns of fluid flow, heat flow, and composition of pore water. Site 855 is located in an area with low heat flow near a normal fault that is a conduit for bottom seawater to enter basement. Dissolved silica at this site is governed by diffusion and dissolution of amorphous silica. At the other three sites (856-858), hydrothermal processes, both past and present, promote the reaction of amorphous silica to quartz. This diagenetic transition is characterized by decreases in the concentrations of dissolved and amorphous silica with depth. Concentrations of amorphous silica decrease with depth from values greater than 1 weight percent (wt\%) $\mathrm{SiO}_{2}$ typical of sediments at Site 855 to about $0.2 \mathrm{wt} \% \mathrm{SiO}_{2}$, whereas concentrations of dissolved silica at depth are generally less than those calculated for equilibrium with chalcedony or quartz. Interpretation of dissolved silica data is limited by the fact that above $50^{\circ} \mathrm{C}$, extraction of pore water by squeezing sediment results in lower concentrations of dissolved silica than those obtained using in-situ sampling techniques.

Present and past patterns of pore-water circulation in Middle Valley are complex, but the amorphous silica data provide some insights. Site 856 is located on an uplifted hill where sill intrusions and/or hydrothermal flow related to the Site 856 sulfide body probably caused pore-water flow that depleted amorphous silica from all but the uppermost part of the sediment column. The objective at Site 857 was to drill into a hydrothermal reservoir. Based on the dissolved and amorphous silica data, we find no evidence of recent vertical pore-water flow. Lastly, Site 858 is located in an area of active hydrothermal venting. Measured profiles of dissolved and amorphous silica concentrations indicate that lateral, vertical, and past vertical pore-water flow influence the diagenesis of amorphous silica at this site.
\end{abstract}

\section{INTRODUCTION}

Holes were drilled at four sites during Ocean Drilling Program (ODP) Leg 139 in Middle Valley, Juan de Fuca Ridge, in order to aid in understanding the pattern of fluid circulation and diagenesis in the sediment column and upper basement (Fig. 1). Each of the four sites has a distinct physical and chemical setting, which will be described in the following sections. Because of the diverse patterns of fluid flow, heat flow, and composition of pore water found at these sites, sediments from Leg 139 provide a unique set of samples to study diagenetic processes. Shipboard results provide much of the data required to develop models of fluid circulation and provide insights into the degree of sedimentary diagenesis; however, the shipboard data are inadequate for addressing rates and mechanisms of sedimentary diagenesis, for example, the diagenesis of amorphous silica.

During diagenesis, amorphous silica evolves through different crystalline phases as it is transformed by solution-precipitation reactions into quartz. The rates of these transformations depend on temperature, pressure, composition of pore water and sediment, redox state of the pore water, $\mathrm{pH}$, surface area of silica phases, and velocity of fluid flow through the sediment section. Transformation of amorphous silica to quartz typically requires millions of years, but this transformation occurs in much less than a million years in sediments retrieved from Middle Valley. We suggest that the relatively short time required for this transformation is a result of fluid flow, high heat flow, and the composition of pore water. The pattern of fluid circulation in Middle Valley is governed by pressure gradients caused by differen-

\footnotetext{
${ }^{1}$ Mottl, M.J., Davis, E.E., Fisher, A.T., and Slack, J.F. (Eds.), 1994. Proc. ODP, Sci. Results, 139: College Station, TX (Ocean Drilling Program).

${ }^{2}$ SOEST, 1000 Pope Road, University of Hawaii, Honolulu, HI 96822, U.S.A.
}

tial heating in basement. This circulation alters the local heat flow and controls the pathways for chemical reaction, thus probably making the pattern of fluid circulation one of the most important constraints in the diagenesis of amorphous silica in Middle Valley.

Only one model has included fluid flow in predicting the diagenesis of amorphous silica in marine sediments (Wheat, 1990). One of the important results of this work is that diagenesis depends on chemical composition of the pore water in basement and pore-water flow conditions. For example, if the pore water in basement is undersaturated with amorphous silica, then upward flow of pore water through sediment enhances dissolution of amorphous silica. In contrast, if pore water in basement is saturated with amorphous silica, upward flow of pore water through the sediment column retards dissolution of amorphous silica. Increasing the speed of pore-water flow through the sediment column amplifies these relationships. In this paper we present the conceptual idea of this model and relate calculated profiles to measured profiles of dissolved and amorphous silica from Middle Valley to characterize the effects of hydrothermal processes on the diagenesis of amorphous silica and to offer possible patterns of present and past pore-water flow.

\section{METHODS}

Concentrations of dissolved silica were measured in pore waters that were obtained by squeezing whole-round sediment sections. Whole-rounds, 6 to $10 \mathrm{~cm}$ in length, were cut from the cores as soon as the cores were on deck. Sediment was extruded from these wholerounds, scraped to remove the outer, contaminated layer and squeezed in a Carver hydraulic press. No attempt was made to squeeze the sediment samples at in-situ temperatures, which ranged from $2^{\circ}$ to $>250^{\circ} \mathrm{C}$. Pore waters were collected in $50-\mathrm{mL}$ all-plastic syringes, filtered through $0.2-\mu \mathrm{m}$ polysulfone filters mounted in a Gelman "acrodisc" disposable filter holder, and analyzed for dissolved silica within 


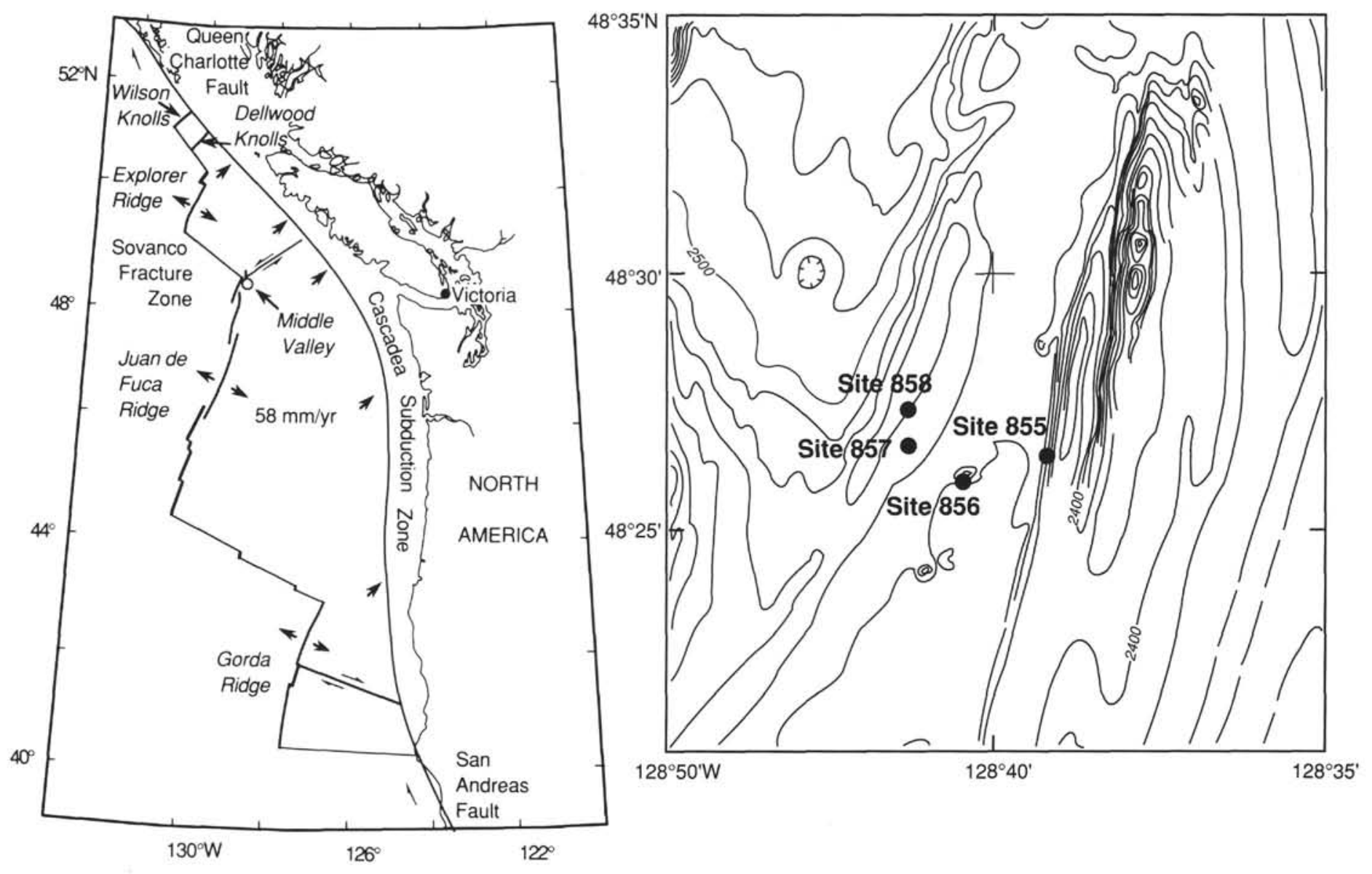

Figure 1. Location of Middle Valley in context of the tectonic setting of the northern Juan de Fuca Ridge and Leg 139 drilling sites in context with the local bathymetry (in meters).

several days of retrieval using a colorimetric technique with a precision of about 3\% (Gieskes and Peretsman, 1986) (Table 1). Several samples were diluted five-fold and analyzed by inductively coupled plasma atomic emission spectrometry to confirm the lack of polymerization of dissolved silica before the sample was analyzed at sea.

Pore waters also were obtained using an in-situ wireline extraction tool (WSTP) (Barnes, 1988) that simultaneously measured sediment temperature (Shipboard Scientific Party, 1992a). Concentrations of dissolved silica were determined at sea in pore waters retrieved from the $10-\mathrm{mL}$ titanium sample coil and the overflow reservoir in the WSTP. These samples provide a basis for examining artifacts caused by core retrieval and sediment squeezing. It is important to note that these data provide the first opportunity to distinguish possible artifacts caused by squeezing sediment samples with in-situ temperatures greater than $25^{\circ} \mathrm{C}$. These artifacts are discussed in association with data interpretation.

Concentrations of amorphous silica were measured in freezedried, ground sediments using the technique described by DeMaster (1981) (Table 2). This technique consists of taking 15 to $30 \mathrm{mg}$ of sediment and exposing it to a $1 \%$ sodium carbonate leach for $24 \mathrm{hr}$, during which time aliquots are taken and analyzed for dissolved silica (Gieskes and Peretsman, 1986). The concentration of amorphous silica is calculated from the $y$ intercept of the linear relationship between dissolved silica and time. The precision is less than $8 \%$. Because silica leached from detrital aluminosilicates in some samples provided up to $50 \%$ of the dissolved silica after $4 \mathrm{hr}$, we could not use the method described by Mortlock and Froelich (1989).

\section{A MODEL OF AMORPHOUS SILICA DIAGENESIS}

A model developed by Wheat (1990) was used to calculate representative depth profiles illustrating the effects of diffusion, advection, and reaction on amorphous silica and dissolved silica concentrations. The model profiles provide a basic understanding of the expected profiles of dissolved and amorphous silica under given hydrologic, geochemical, and sedimentological conditions, from which we surmise the processes that control the more complex observed profiles. In this section we will explain the shape of representative profiles calculated from a coupled amorphous silica-dissolved silica model (Wheat, 1990). We then compare the measured profiles with these profiles in the following sections.

The model includes terms for pore-water diffusion and advection, sedimentation, and reaction. The reaction term accounts only for the dissolution of amorphous silica, which is the dominant early diagenetic process that influences profiles of dissolved silica (Fanning and Pilson, 1974). The model, at present, does not include reaction of other silica phases, such as chalcedony or quartz, because of the added complexities; however, this does not detract from our goal of using the model to understand the more complex measured profiles. Although dissolution of amorphous silica is controlled by surface reactions (Berner, 1978), we chose a rate constant that is proportional to the degree of undersaturation of amorphous silica in the pore water (Schink et al., 1975) and proportional to the concentration of amorphous silica, thus producing a coupled amorphous silica-dissolved silica reaction term. Assuming that the diffusion coefficient, rates of 
Table 1. Weight percentage of amorphous silica as $\mathrm{SiO}_{2}$.

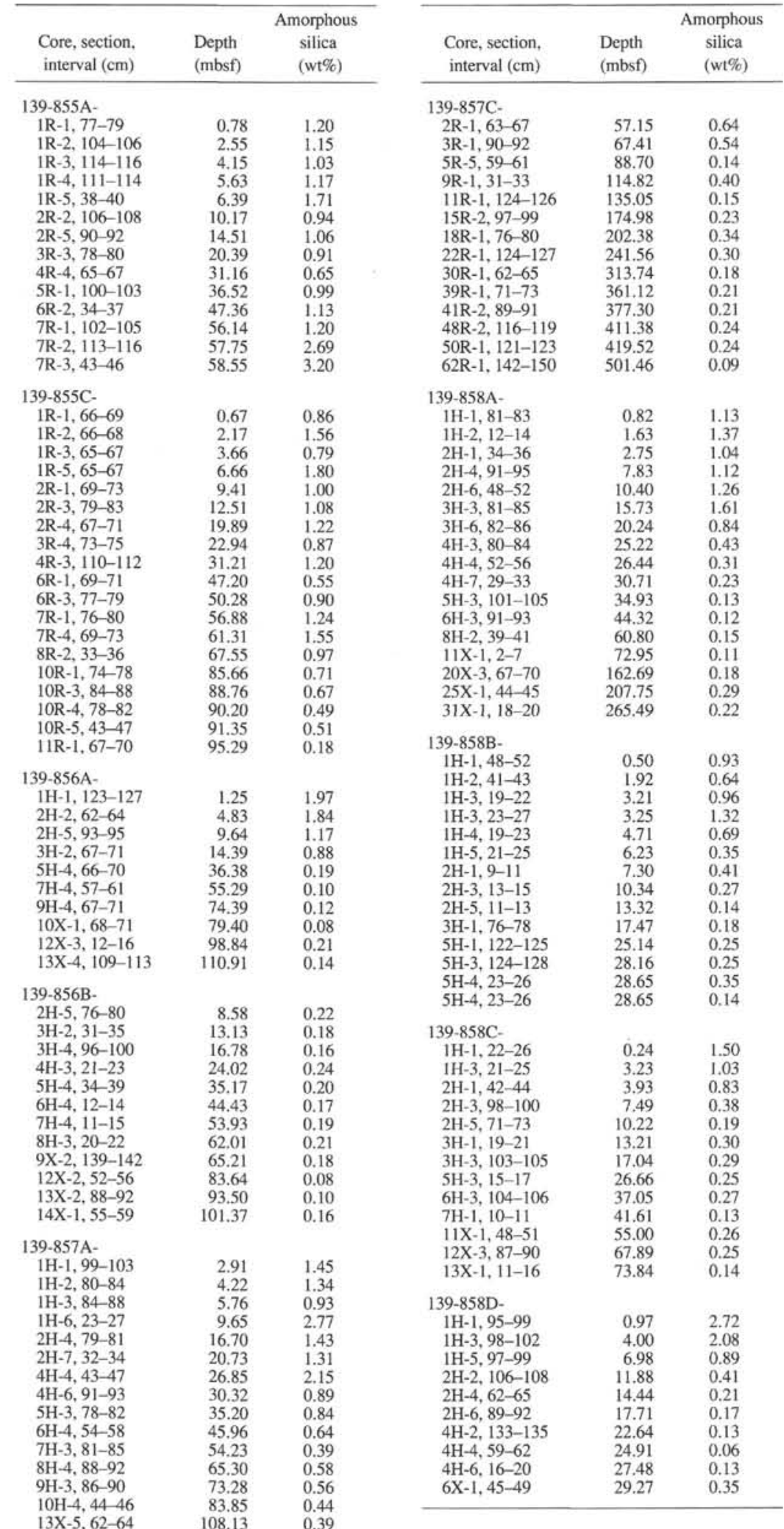




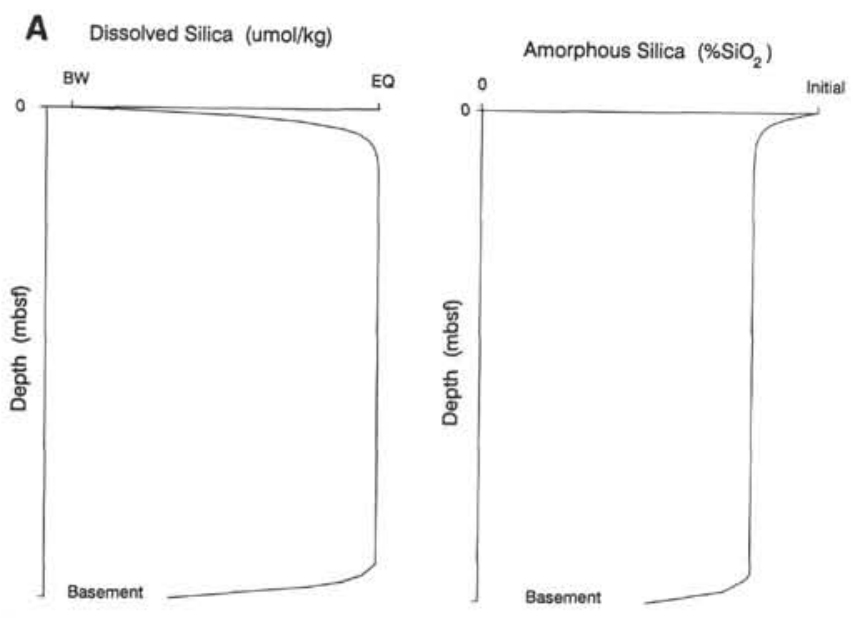

B Dissolved Silica (umol/kg)
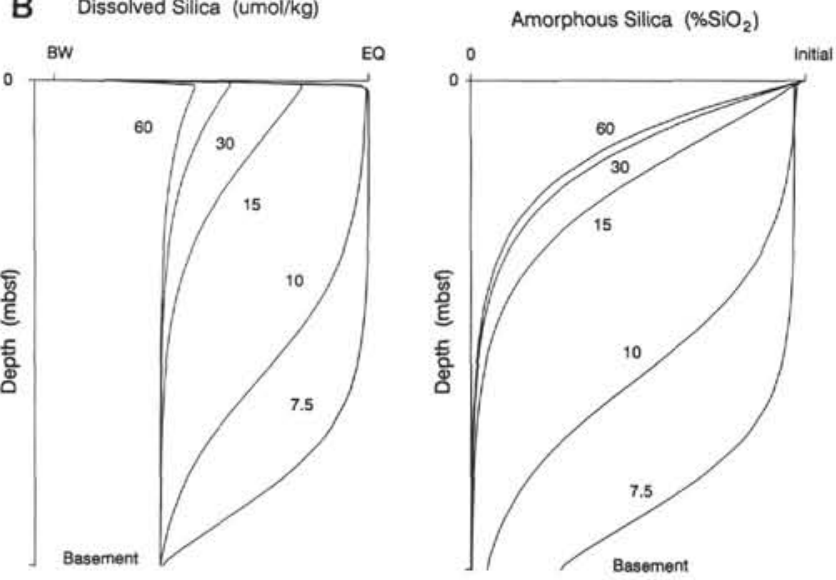

Figure 2. Calculated profiles of dissolved and amorphous silica with no vertical pore-water flow (A) and with vertical pore-water upwelling (B). BW is the bottom seawater value. EQ is the value in equilibrium with the sediments. Zero ( 0 ) and basement define the sediment thickness, and initial is the concentration of amorphous silica at the sediment-water interface. Numbers in (B) are speeds in centimeters per year used to calculate the profiles.

advection, sedimentation, and reaction, and porosity are uniform with depth, the steady-state model in one-dimension is:

$$
\begin{gathered}
D_{s} \frac{\delta^{2} S i}{\delta z^{2}}-v \frac{\delta S i}{\delta z}+\frac{k A}{\phi S i_{e q}}\left(S i_{e q}-S i\right)=0, \\
-w \frac{\delta A}{\delta z}-\frac{k A}{S i_{e q}}\left(S i_{e q}-S i\right)=0,
\end{gathered}
$$

where $D_{s}$ is the sediment diffusion coefficient for dissolved silica, $S i$ is the concentration of dissolved silica, $z$ is depth (positive down), $v$ is pore-water vertical velocity (upwelling is negative), $k$ is the firstorder rate of reaction, $A$ is the concentration of amorphous silica, $\phi$ is porosity, $S i_{e q}$ is the pseudo-equilibrium concentration from the dissolution of amorphous silica, and $w$ is the rate of sedimentation. Equations 1 and 2 form a nonlinear system that is solved using a RungeKutta shooting technique (Wheat, 1990).

The usefulness of this model is enhanced by the inclusion of an advective term and coupling terms for the concentrations of dissolved and amorphous silica in the reaction term; however, this model makes no provisions to include a temperature dependence for the rate of reaction or reaction with various polymorphs of silica. Because the model is based on steady state, it cannot account for variable rates of amorphous silica input at the sediment-water interface or changes in the upwelling speed of pore-water flow, which also influence the temperature regime. These non-steady-state processes are difficult to quantify in any context and substantially increase the complexity of the calculations. Most of our assumptions produce second-order effects on the shape of modeled profiles and are designed to minimize the complexity of the nonlinear equations. Some of the chemical and physical processes that affect diagenesis of amorphous silica in Middle Valley sediments are not included in the model, but the model permits evaluation of the effects of basement pore-water composition and the speed of pore-water flow on diagenesis of amorphous silica. The above-mentioned chemical and physical parameters have a strong influence on the profiles of dissolved and amorphous silica, and, therefore, our model calculations provide fundamentally important profiles for qualitative and illustrative purposes.

Calculated profiles from equations 1 and 2 are shown in Figure 2. These profiles are presented to illustrate the effects of pore-water flow on the diagenesis of amorphous silica. The profiles are calculated using generic parameters for the concentrations of dissolved silica in bottom water, in equilibrium with amorphous silica, and in basement, for concentrations of amorphous silica at the sediment water interface, for a particular rate of reaction, and for various pore-water upwelling speeds.

Figure $2 \mathrm{~A}$ presents calculated profiles of dissolved and amorphous silica that are expected in areas without pore-water flow, other than that associated with consolidation of sediment. As expected, the concentration of dissolved silica increases in the upper sediment column because bottom seawater is undersaturated with amorphous silica. This increase is compensated by a decrease in the concentration of amorphous silica. Concentrations of dissolved silica increase until equilibrium is attained, then concentrations of dissolved and amorphous silica remain uniform with depth. Near the sediment-basalt interface, changes in dissolved and amorphous silica are predicted, because the concentration of dissolved silica in basement is assumed to be in equilibrium with quartz, which is less soluble than amorphous silica. To compensate for a diffusional flux of dissolved silica to basement, amorphous silica must dissolve, thus reducing the concentration of amorphous silica near the sediment-basement interface.

Figure $2 \mathrm{~B}$ presents calculated profiles of dissolved and amorphous silica that are expected in areas with upwelling pore waters that are flowing at different speeds on the order of centimeters per year. Given seawater in basement that is in equilibrium with quartz, or at least undersaturated with amorphous silica, dissolution of amorphous silica occurs as pore water upwells through the sediment. Dissolution continues until equilibrium is reached. If the upwelling speed is slow enough (on the order of several $\mathrm{cm} / \mathrm{yr}$ ), or the sediment column is thick enough (tens to hundreds of meters thick), then upwelling pore waters reach saturation with amorphous silica and dissolution ceases. Under these conditions, the concentration of amorphous silica in the upper portion of the sediment column will exceed that in areas without flow where pore waters are undersaturated with amorphous silica (e.g., compare the profile with an upwelling speed of $7.5 \mathrm{~cm} / \mathrm{yr}$ in Fig. 2B, with the no-flow profile in Fig. 2A). However, if the speed of upwelling pore water is fast enough (tens to hundreds of $\mathrm{cm} / \mathrm{yr}$ ), equilibrium is never obtained and dissolution continues throughout the sediment column. This may result in complete removal of amorphous silica near the base of the sediment section. An increase in the upwelling speed or an increase in the rate of reaction results in dissolution of more amorphous silica throughout the sediment column. Note that even in areas with fast pore-water upwelling speeds, the concentration of amorphous silica in the upper sediment column may be greater than the concentration in the no-flow case and it always approaches 
the concentration at the sediment-water interface because of a constant supply of amorphous silica from the water column.

\section{RESULTS AND DISCUSSION}

In this section we present the measured profiles of dissolved and amorphous silica from Middle Valley and compare them to representative profiles calculated from the model. This comparison allows us to evaluate the processes that influence the shape of the measured profiles.

\section{Site 855}

The four holes drilled at Site 855 on the eastern side of the Middle Valley rift (Fig. 1) lie along a transect perpendicular to a normal fault with an apparent dip of about $45^{\circ}$ (Shipboard Scientific Party, 1992b). The throw of the fault is about $25 \mathrm{~m}$ greater than the local sediment thickness, causing basement to be exposed. Holes were drilled through sediment of the hanging wall $40 \mathrm{~m}$ from the outcrop (Hole 855B) and $70 \mathrm{~m}$ from the outcrop (Hole 855A) and into basement of the footwall. The other two holes were drilled through sediment and into basement of the hanging wall about $125 \mathrm{~m}$ from the outcrop (Holes 855C and 855D).

Shipboard interpretations of the pore-water chemical data concluded that this fault is a conduit for flow of bottom seawater into basement (Shipboard Scientific Party, 1992b). Flow along the fault or directly into the exposed basement suppresses the local heat flow and results in a basement fluid that closely resembles bottom seawater in its chemical composition. Although there is bottom seawater flow along the fault, vertical pore water flow through the sediment section is less than $1 \mathrm{~mm} / \mathrm{yr}$, based on chloride data that show a chloride maximum at a depth of about $30 \mathrm{mbsf}$. This maximum is produced by diffusion of bottom seawater, which varies systematically between glacial and interglacial periods, into the sediment section (McDuff, 1985; Wheat and Mottl, in press).

The dissolved and amorphous silica data from Site 855 are presented in Table 1 and Figure 3. Concentrations of dissolved silica increase from bottom seawater $(183 \mu \mathrm{mol} / \mathrm{kg})$ to about $500 \mu \mathrm{mol} / \mathrm{kg}$ in the upper meter of the sediment section. Concentrations generally increase downcore and reach a maximum about $20 \mathrm{~m}$ above basement, below which concentrations decrease with depth. In Hole 855C the concentration of dissolved silica decreases to the value measured in bottom seawater.

Concentrations of amorphous silica in the upper $10 \mathrm{~m}$ of the sediment column at Site 855 are generally greater than 1 weight percent (wt \%) $\mathrm{SiO}_{2}$, but less than $2 \mathrm{wt} \%$. Below 10 mbsf concentrations are close to $1 \mathrm{wt} \%$ with less variance than in the upper $10 \mathrm{mbsf}$. From $56.1 \mathrm{mbsf}$ to $58.6 \mathrm{mbsf}$ in Hole $855 \mathrm{~A}$, concentrations increase to the highest value measured at the site ( $3.2 \mathrm{wt} \%$ ). Unfortunately, no samples were obtained between this sample and basement at $74 \mathrm{mbsf}$. The maximum in Hole $855 \mathrm{~A}$ exists at the same depth as a local maximum in Hole $855 \mathrm{C}$, consistent with shipboard conclusions that all of the Site 855 holes are lithologically similar (Shipboard Scientific Party, 1992b). In the bottommost $10 \mathrm{~m}$ of Hole $855 \mathrm{C}$, the concentrations of amorphous silica decrease from about $1 \mathrm{wt} \%$ to 0.18 wt $\%$ in the deepest sample $2.2 \mathrm{~m}$ from basement.

Profiles of dissolved and amorphous silica from Site 855 provide an example of early diagenesis of amorphous silica in sediments where pore-water flow is absent. The assumption of no flow is based on the chloride data and the similarity of the measured profiles in Figure 3 and the calculated profiles in Figure 2A. Both the measured and calculated profiles show increases in the concentration of dissolved silica in the upper section of the sediment column. With increasing sediment depth, calculations of the model result in a uniform concentration; measured values, however, increase because of the increase in solubility resulting from the increase in temperature with depth. Both the calculated and measured profiles show decreases
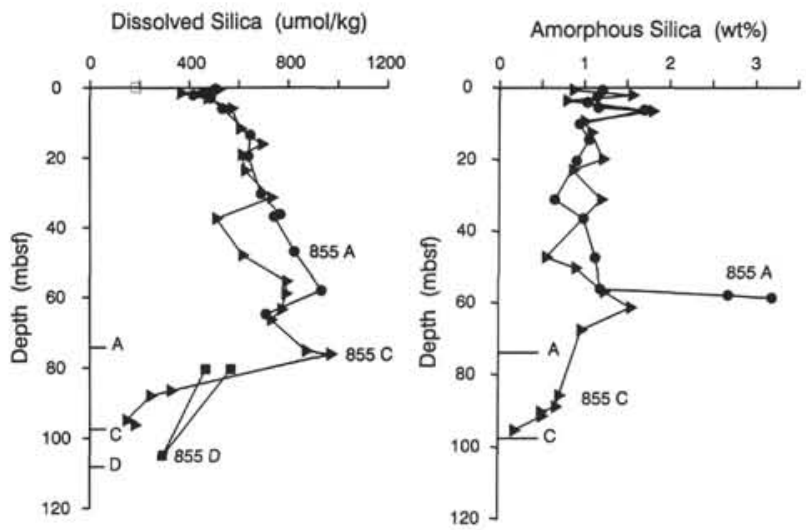

Figure 3. Measured profiles of dissolved and amorphous silica from Site 855. Samples 139-855C-6R-1, 140-150 cm; 855C-6R-6, 140-150 cm; and 855D$1 \mathrm{I}-1,74-97 \mathrm{~cm}$, have been adjusted for dilution with surface seawater. Sample 855D-1I-1, 74-97 cm, also has been adjusted for dilution with distilled water. Letters define the depth to basalt for each hole.

in the concentration of dissolved silica near basement. Presumably this is because basement pore water is similar to bottom seawater and thus is undersaturated with amorphous silica. In fact, concentrations of dissolved silica in pore-water samples closest to the sediment-basement interface in Hole $855 \mathrm{C}$ are equal to bottom seawater values, implying that the advective flux of bottom seawater into basement along the fault is large compared to the diffusional flux of dissolved silica from the sediment column.

The measured profiles of amorphous silica at Site 855 are similar to the calculated profile of Figure $2 \mathrm{~A}$. The calculated profile predicts a decrease in the concentration of amorphous silica in the upper sediment section; the scatter in the upper $10 \mathrm{~m}$ of the measured profile is consistent with this decrease. The average concentration of amorphous silica of about $1 \mathrm{wt} \%$ between 10 mbsf and about $70 \mathrm{mbsf}$ is similar to the uniform concentration at intermediate depths in the calculated profile. Both the calculated profile and the measured profile at Hole $855 \mathrm{C}$ show a decrease near the sediment-basement interface. The local maxima about $60 \mathrm{mbsf}$ in the measured profiles are probably a result of a depositional layer high in amorphous silica. The smaller maximum at 61.31 mbsf in Hole $855 \mathrm{C}$ compared with the maximum at 58.55 mbsf in Hole $855 \mathrm{~A}$ could result from an inadequate sample density between 56.9 and $61 \mathrm{mbsf}$ in Hole $855 \mathrm{C}$ that may have missed the layer rich in amorphous silica.

Differences between the measured and calculated profiles are presumed to be the result of temporal changes in the flux of amorphous silica to the sediments, a change that is not included in the present model. Below the maximum in amorphous silica in Hole $855 \mathrm{~A}$, concentrations of amorphous silica probably decrease. This conclusion is supported by the measured decrease in the concentration of dissolved silica that reflects a flux of dissolved silica from the sediment into basement. This flux requires dissolution of amorphous silica in the sediment column. If the seawater in basement has always been undersaturated with amorphous silica, one would expect that dissolution of amorphous silica near the base of the sediment column has always occurred. Eventually amorphous silica will be completely removed near the sediment-basement interface.

Because of the low measured temperature gradient $\left(0.33^{\circ} \mathrm{C} / \mathrm{m}\right)$, the relatively thin sediment section $(<110 \mathrm{~m})$, and the young age of the underlying basement ( $<400$ k.y.) (Shipboard Scientific Party, 1992b), one would expect dissolved silica to be in equilibrium with amorphous silica throughout the sediment column except near the sediment-water and sediment-basalt interfaces. Because of the low heat flow and the lack of pore-water flow through the sediment section, we expect little amorphous silica to be transformed into more crystalline forms such as chalcedony or quartz. 

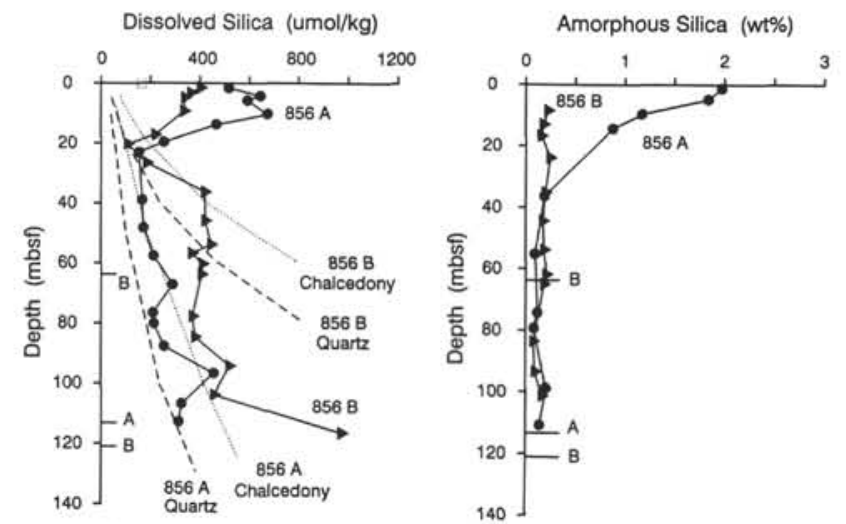

Figure 4. Measured profiles of dissolved and amorphous silica from Site 856 with calculated equilibrium curves based on Walther and Helgeson (1977) and the measured temperature gradient (Shipboard Scientific Party, 1992c). Letters define the depth to sills in each hole.

\section{Site 856}

Eight holes were drilled at Site 856, a site of hydrothermal discharge located about $3 \mathrm{~km}$ from Sites 855 and 858 (Fig. 1). Six of these holes were drilled into a massive sulfide mound that consists mostly of pyrite and pyrrhotite (Shipboard Scientific Party, 1992c). Only one pore-water sample was obtained from these cores because of the granular nature of the sediment in the upper sediment column and the presence of massive sulfide throughout the cores. In contrast, pore waters were extracted from more than 16 samples in Holes $856 \mathrm{~A}$ and $856 \mathrm{~B}$, which are located several hundred meters north of the massive sulfide mound on Bent Hill, a circular hill about $500 \mathrm{~m}$ in diameter and $60 \mathrm{~m}$ in height.

Hole $856 \mathrm{~A}$ was drilled into the center of Bent Hill and Hole 856B was drilled on the southern flank where the water depth is about $25 \mathrm{~m}$ greater. Sills were encountered at about $113 \mathrm{mbsf}$ in Hole 856A and about $121 \mathrm{mbsf}$ in Hole 856B. A thin sill was encountered in Hole $856 \mathrm{~B}$ at about $62 \mathrm{mbsf}$. The intrusion of these sills probably caused uplift of the hill. Pore-water flow through the sediment column at this site could have resulted from emplacement of the sills or from hydrothermal flow related to the Site 856 sulfide body (Mottl et al., this volume).

The presence of flow is confirmed from interpretation of porewater chemistry and sediment mineralogy; however, flow may not be occurring at present. Based on pore-water chloride data, pore-water flow must have occurred in the past $10 \mathrm{k}$.y (Shipboard Scientific Party, 1992c). The presence of anhydrite, determined by X-ray diffraction (XRD) in Hole 856A (Samples 139-856A-8H-1, 115-117 cm, 60.0 mbsf, and $856 \mathrm{~A}-8 \mathrm{H}-3,102-105 \mathrm{~cm}, 62.8 \mathrm{mbsf}$ ), and anhydrite molds (86.2 to 113.22 mbsf in Hole $856 \mathrm{~A}$ and 39.8 to $65.44 \mathrm{mbsf}$ in Hole 856B) (Shipboard Scientific Party, 1992c) suggests that pore-water temperatures have been at least $150^{\circ} \mathrm{C}$, the temperature required to precipitate anhydrite from seawater. At least six pore volumes of seawater are required to supply enough sulfate to produce an anhydrite deposit that represents $2 \%$ of the bulk sediment with a porosity of $70 \%$.

Concentrations of dissolved silica in both holes increase from bottom seawater values to greater than $400 \mu \mathrm{mol} / \mathrm{kg}$ in the shallowest sample (Fig. 4). Concentrations increase in Hole 856A to a maximum at $10.15 \mathrm{mbsf}$, then decrease to a minimum at $23.15 \mathrm{mbsf}$. Concentrations generally increase with depth below $23.15 \mathrm{mbsf}$. In Hole $856 \mathrm{~B}$, concentrations decrease from $402 \mu \mathrm{mol} / \mathrm{kg}$ at $1.47 \mathrm{mbsf}$ to about 100 $\mu \mathrm{mol} / \mathrm{kg}$ at $20.25 \mathrm{mbsf}$. Concentrations then increase to about 420 $\mu \mathrm{mol} / \mathrm{kg}$ at $36.35 \mathrm{mbsf}$ and remain fairly uniform with depth, except for the deepest sample with a concentration of $970 \mu \mathrm{mol} \mathrm{Si} / \mathrm{kg}$ at 116.35 mbsf.
Concentrations of amorphous silica decrease from about 2 wt $\%$ $\mathrm{SiO}_{2}$ near the surface in Hole $856 \mathrm{~A}$ to $0.19 \mathrm{wt} \%$ at $36.38 \mathrm{mbsf}$, then remain uniform with depth (Fig. 5, Table 1). Concentrations in Hole $856 \mathrm{~B}$ are uniform with depth below $8.6 \mathrm{mbsf}$ with values of about $0.19 \mathrm{wt} \%$. No samples were available for analysis at depths shallower than 8.6 mbsf.

Profiles of dissolved silica from Site 856 (Fig. 4) are not consistent with profiles calculated from our basic advection-diffusion-reaction model (Fig. 2). Instead, these profiles reflect equilibrium of the pore waters with different phases of silica as the increase in temperature downcore aids in the transition of amorphous silica to quartz. In the upper $10 \mathrm{mbsf}$, concentrations of dissolved silica are controlled by diffusion and dissolution of amorphous silica. Below $20 \mathrm{mbsf}$ dissolved silica concentrations reflect the reactions of silica diagenesis. Comparison of measured profiles with equilibrium curves calculated for chalcedony and quartz indicate the transition from chalcedony to quartz probably occurs at about $97 \mathrm{mbsf}$ in Hole 856 A and about 54 mbsf in Hole 856B. These are minimum depths because concentrations of dissolved silica below 54 mbsf in Hole 856B indicate undersaturation with quartz (Walther and Helgeson, 1977) for the measured temperature gradient $\left(1.27^{\circ} \mathrm{C} / \mathrm{m}\right)$ (Shipboard Scientific Party, 1992c). The low concentrations of dissolved silica are probably sampling artifacts because the WSTP sample from 96.55 mbsf in Hole 856A indicates pore-water equilibrium with chalcedony whereas neighboring samples obtained by squeezing are in equilibrium with quartz. An alternative hypothesis for the lower than expected values of dissolved silica below $54 \mathrm{mbsf}$ is that pore waters are not in equilibrium with any silica phase because of recent pore-water flow generated by sill intrusion.

Profiles of amorphous silica (Fig. 4) are consistent with model calculations with pore-water upwelling (Fig. 2B). We cannot calculate the rate of flow or the duration of flow using the model presented earlier, because the model assumes steady state and we do not know the history of fluid flow. We can conclude, however, that pore-water flow has existed and that this pore water was undersaturated with amorphous silica. No evidence exists for present-day flow, but profiles of chlorinity are consistent with flow in the past $10 \mathrm{k} . \mathrm{y}$.

\section{Site 857}

Four holes were drilled within about $200 \mathrm{~m}$ of one another at Site 857 , which is located about $5 \mathrm{~km}$ west of Site 855 where bottom seawater flows into basement (Fig. 1). Site 857 also is about $1.5 \mathrm{~km}$ south of Site 858 , where seawater that has been chemically altered exits basement through a sediment cover at temperatures up to $276^{\circ} \mathrm{C}$ (Butterfield et al., this volume). Pore-water and sediment chemistry reveal a complex history of lateral fluid flow throughout the drilled sediment column at Site 857 (936 mbsf) (Shipboard Scientific Party, 1992d). Below 100 mbsf the sediment becomes increasingly indurated with depth. The first of a series of sills was drilled at $471 \mathrm{mbsf}$, below which the sediment becomes progressively more silicified. At the base of Hole $857 \mathrm{D}$ (936 mbsf) temperatures are at least $280^{\circ} \mathrm{C}$ (Davis and Wang, this volume; Villinger et al., this volume).

Concentrations of dissolved silica at Site 857 increase from bottom-water values to about $475 \mu \mathrm{mol} / \mathrm{kg}$ in the shallowest sample (Fig. 5 , Table 1). Concentrations increase to about $990 \mu \mathrm{mol} / \mathrm{kg}$ at $37.4 \mathrm{mbsf}$ and then decrease to about $300 \mu \mathrm{mol} / \mathrm{kg}$ at $70 \mathrm{mbsf}$. Below $70 \mathrm{mbsf}$ concentrations remain generally uniform with depth. The deepest sample analyzed is from $686 \mathrm{mbsf}, 250 \mathrm{~m}$ from the bottom of the hole.

Concentrations of amorphous silica are generally greater than 1 $w t \%$ in the upper 26.9 mbsf with two local maxima, then decrease to about 0.2 wt $\%$ over the next $110 \mathrm{~m}$ (Fig. 5). Below 240 mbsf concentrations remain uniform to 501.5 mbsf. No samples were analyzed below 501.5 mbsf. XRD analyses indicate that sediment retrieved from below the first sill contains more quartz than that above, except for the depth interval from 140 to 210 mbsf. Lateral transport of pore water between about $200 \mathrm{mbsf}$ to $500 \mathrm{mbsf}$ has been postulated 

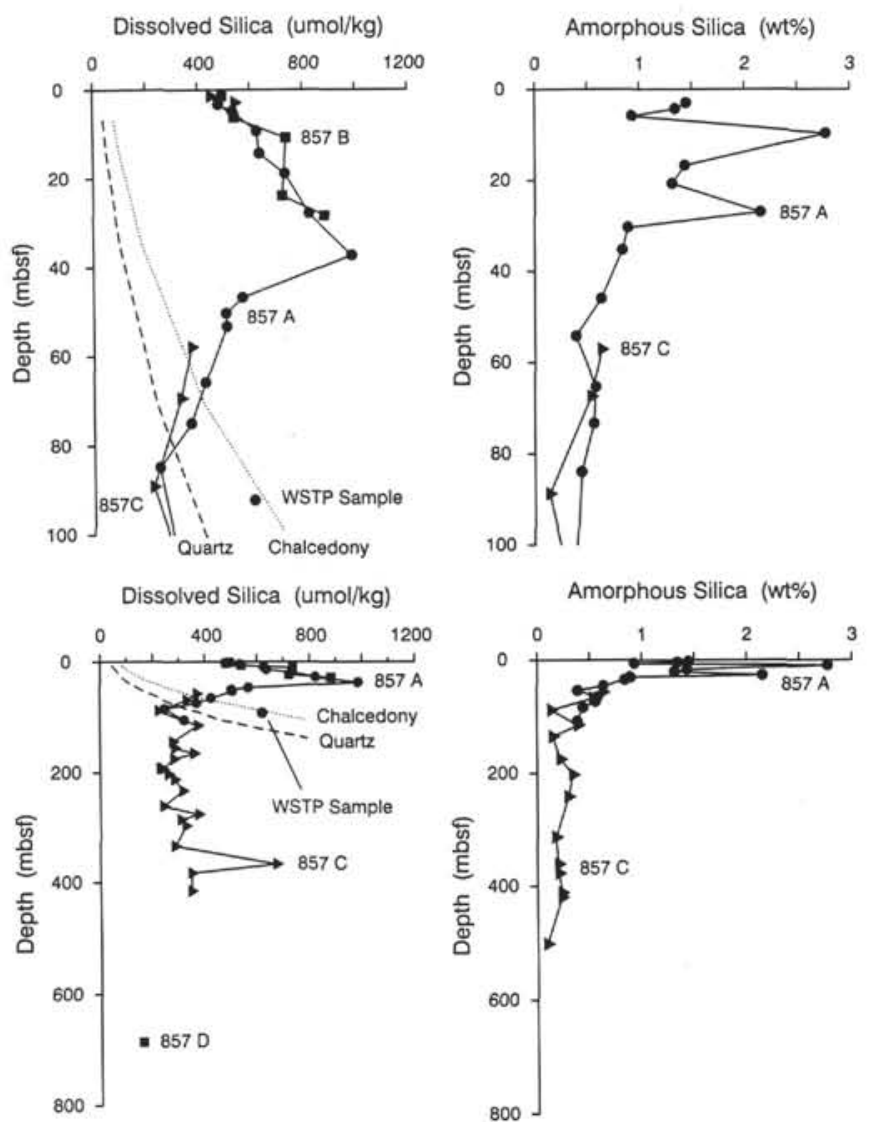

Figure 5. Measured profiles of dissolved and amorphous silica from Site 857 with calculated equilibrium curves based on Walther and Helgeson (1977) and the measured temperature gradient (Shipboard Scientific Party, 1992d). Two depth scales are presented for comparison with the other sites.

(Shipboard Scientific Party, 1992d) and it may be the controlling factor for the lower abundances of quartz in this depth interval.

Profiles of dissolved and amorphous silica are consistent with a temperature-dependent transition from amorphous silica to quartz. In the upper $40 \mathrm{mbsf}$, concentrations of dissolved silica are controlled by diffusion and reaction with amorphous silica. Concentrations of dissolved silica increase in this interval because of the temperature dependence of amorphous silica solubility. Temperature increases by $0.61^{\circ} \mathrm{C} / \mathrm{m}$ in Hole $857 \mathrm{~A}$ (Shipboard Scientific Party, 1992d). Concentrations of amorphous silica are generally greater than $1 \mathrm{wt} \%$ in the upper $40 \mathrm{mbsf}$; values are not uniform because of temporal changes in the sedimentary inputs at the sediment-water interface.

In the interval from 40 to $80 \mathrm{mbsf}$, concentrations of dissolved and amorphous silica generally decrease with depth, probably because of the transformation of amorphous silica to chalcedony, a reaction that is accelerated by the high thermal gradient. Below 106 mbsf, concentrations of dissolved silica from squeezed samples are uniform with depth and well below the calculated concentration for quartz equilibrium. This is probably a result of sample handling, as no attempt was made to squeeze the sediment samples at in-situ temperatures that range from $2^{\circ} \mathrm{C}$ to $280^{\circ} \mathrm{C}$. A WSTP sample at $91.9 \mathrm{mbsf}$ in Hole 857A contains dissolved silica in equilibrium with chalcedony. This sample has a concentration that is about $300 \mu \mathrm{mol} / \mathrm{kg}$ greater than neighboring squeezed samples. This discrepancy shows clearly the effects of squeezing sediments with in-situ temperatures greater than $50^{\circ} \mathrm{C}$. The transition from chalcedony to quartz probably occurs at about $135 \mathrm{mbsf}$, where amorphous silica reaches a minimum. The shape of the amorphous silica profile is consistent with no recent vertical pore-water flow.
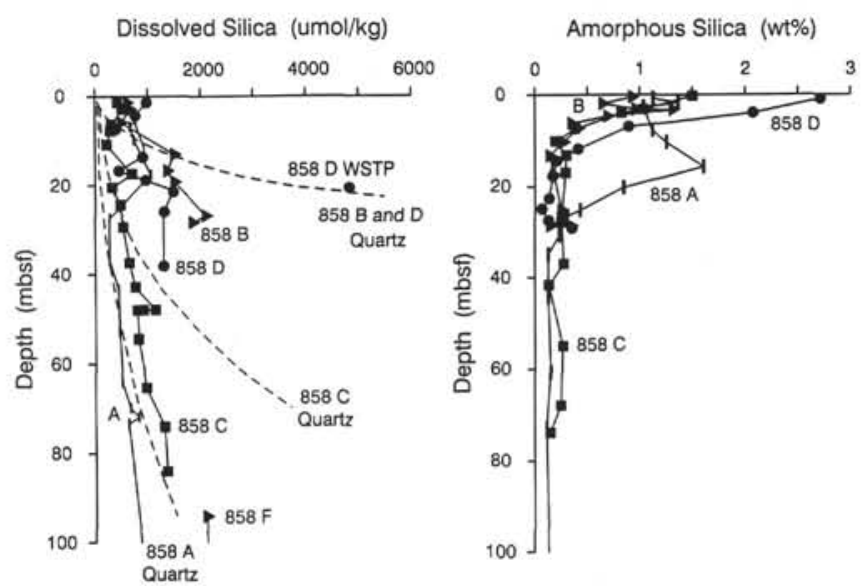

Figure 6. Measured profiles of dissolved and amorphous silica from Site 858 with calculated equilibrium curves based on Walther and Helgeson (1977) and the measured temperature gradient (Shipboard Scientific Party, 1992e). Only the upper 100 mbsf are shown.

At $470 \mathrm{mbsf}$ in Hole $857 \mathrm{C}$ the temperature is estimated to be about $280^{\circ} \mathrm{C}$ (Davis and Wang, this volume; Villinger et al., this volume). At this temperature, pore water in equilibrium with quartz should have a dissolved silica concentration of $8 \mathrm{mmol} / \mathrm{kg}$, but measured values are about $0.35 \mathrm{mmol} / \mathrm{kg}$. If dissolved silica is removed from pore water by precipitation as amorphous silica during sample handling, then the measured $\mathrm{wt} \% \mathrm{SiO}_{2}$ should be at least $0.18 \mathrm{wt} \%$ for a sample with a porosity of $50 \%$. Measured values of amorphous silica are of the same magnitude (Table 1).

\section{Site 858}

Site 858 is located in a hydrothermal discharge zone that occupies an area about $800 \mathrm{~m}$ along the strike of Middle Valley and about 400 $\mathrm{m}$ in width, where some conductive heat flow measurements exceed $20 \mathrm{~W} / \mathrm{m}^{2}$ (Davis and Villinger, 1992) and where fluids exit the seafloor at temperatures up to $276^{\circ} \mathrm{C}$ (Shipboard Scientific Party, 1992e) (Fig. 1). We present data from the four holes (Hole 858A, 858B, 858C, and $858 \mathrm{D}$ ) that form a transect from about $150 \mathrm{~m}$ west of the active vents (Hole $858 \mathrm{~A}$ ) to $70 \mathrm{~m}$ west of the active vents (Hole $858 \mathrm{C}$ ) to several $\mathrm{m}$ from the active vents (Hole $858 \mathrm{~B}$ ). Hole $858 \mathrm{D}$ was positioned about $70 \mathrm{~m}$ northwest of Hole $858 \mathrm{~B}$, about $50 \mathrm{~m}$ from the nearest vent.

Sediment in each of these holes is hydrothermally altered (Shipboard Scientific Party, 1990e). Fluid flow in the upper 50 mbsf of Holes $858 \mathrm{~B}$ and $858 \mathrm{D}$ has caused pore-water chemical compositions and temperatures to differ markedly between these holes and Holes $858 \mathrm{~A}$ and $858 \mathrm{C}$. A lateral component of pore-water flow through the sediment of Holes $858 \mathrm{~B}$ and $858 \mathrm{D}$ exists, but profiles of pore-water chemical composition indicate that this flow is a non-steady-state process (Shipboard Scientific Party, 1992e). We expect that the differences in the temperature gradient and pore-water flow regime through the sediment should cause diagenesis of amorphous silica to be different in each of these holes.

Concentrations of dissolved silica in pore waters from Site 858 range from 220 to $4830 \mu \mathrm{mol} / \mathrm{kg}$ (Fig. 6). In Hole 858A concentrations increase from bottom-water values to $1050 \mu \mathrm{mol} / \mathrm{kg}$ at 17.62 mbsf, decrease to $270 \mu \mathrm{mol} / \mathrm{kg}$ at $27.35 \mathrm{mbsf}$, then generally increase with depth to $1700 \mu \mathrm{mol} / \mathrm{kg}$ at $>246 \mathrm{mbsf}$. Hole $858 \mathrm{~B}$ has concentrations of dissolved silica that generally increase with depth and reach a maximum of $2100 \mu \mathrm{mol} / \mathrm{kg}$ at $26.87 \mathrm{mbsf}$. Concentrations of dissolved silica in Hole $858 \mathrm{C}$ have a local maximum of $520 \mu \mathrm{mol} / \mathrm{kg}$ at $2.97 \mathrm{mbsf}$, but concentrations generally increase to $1360 \mu \mathrm{mol} / \mathrm{kg}$ at $84.1 \mathrm{mbsf}$. Concentrations in Hole 858D increase to a maximum of $4830 \mu \mathrm{mol} / \mathrm{kg}$ at $20.7 \mathrm{mbsf}$, then decrease with depth. 
Concentrations of amorphous silica approach values less than 0.2 wt $\%$ at the base of all four holes analyzed at Site 858 (Fig. 6, Table 1). Concentrations of amorphous silica in Hole $858 \mathrm{~A}$ are generally above $1 \mathrm{wt} \%$ in the upper $15.7 \mathrm{mbsf}$ then decrease to baseline levels (about $0.2 \mathrm{wt} \%$ ) about $34.9 \mathrm{mbsf}$. Concentrations in Hole $858 \mathrm{~B}$ reach a local maximum at $3.25 \mathrm{mbsf}$ then decrease to a baseline level at 13.3 mbsf. Both Holes $858 \mathrm{C}$ and $858 \mathrm{D}$ have concentrations of amorphous silica that decrease monotonically to baseline levels at $10.2 \mathrm{mbsf}$ in $858 \mathrm{C}$ and $17.7 \mathrm{mbsf}$ in $858 \mathrm{D}$, then remain uniform with depth.

Profiles of dissolved silica from Site 858 are governed by interactions between pore water and sediment and basement, lateral porewater flow, and possible vertical pore-water flow. None of the profiles of dissolved silica match calculated profiles. With the exception of Hole $858 \mathrm{~A}$, profiles of amorphous silica match calculated profiles with vertical pore-water flow. This implies that vertical pore-water flow had existed, but it presently does not contribute significantly to the shape of the dissolved silica profiles.

Profiles from Hole 858A are consistent with dissolved silica in equilibrium with amorphous silica to a depth of about $17.6 \mathrm{mbsf}$ where a decrease in both dissolved and amorphous silica were measured. The transition from pore waters in equilibrium with chalcedony to pore waters in equilibrium with quartz probably occurs at about 34 mbsf, where concentrations of amorphous silica reach baseline levels and concentrations of dissolved silica are consistent with calculated equilibrium values. Below 73.4 mbsf concentrations of dissolved silica are less than the calculated equilibrium values, probably a result of sampling artifacts.

Concentrations of dissolved silica in Hole $858 \mathrm{~B}$ increase to a value in equilibrium with quartz at $13.2 \mathrm{mbsf}$, about the same depth where the concentration of amorphous silica reaches baseline levels. This decrease to baseline levels could be a result of past vertical pore-water flow or high temperatures (about $134^{\circ} \mathrm{C}$ at $13.2 \mathrm{mbsf}$ ) that aid in the transition from amorphous silica to quartz. This depth also coincides with a section believed to be a conduit for lateral flow, based on profiles of pore-water chemical compositions (Shipboard Scientific Party, 1992e).

Profiles of dissolved and amorphous silica from Hole $858 \mathrm{C}$ are similar to those from $858 \mathrm{~A}$ in that (1) a shallow maximum in dissolved silica is coincident with the depth where amorphous silica decreases below $1 \mathrm{wt} \%$ and where amorphous silica is decreasing with depth, (2) equilibrium with quartz is attained at a depth where amorphous silica reaches baseline levels, and (3) the profile of dissolved silica follows the quartz equilibrium trend, then falls below the calculated values. Therefore, the measured profile of dissolved silica is probably a result of equilibrium reactions with the different polymorphs of silica in the upper $29.5 \mathrm{mbsf}$ and sampling artifacts below $29.5 \mathrm{mbsf}$. We believe, however, that the profile of amorphous silica has been shaped by previous vertical pore-water flow. This conclusion is based on the low concentrations of amorphous silica in the upper 10 mbsf of the sediment column.

Concentrations of dissolved silica in Hole $858 \mathrm{D}$ reach values in equilibrium with quartz at $20.7 \mathrm{mbsf}$. This sample was taken from a WSTP overflow sample that was diluted with distilled water, further illustrating that sampling artifacts caused by squeezing lowers the measured concentration of dissolved silica relative to in-situ values. The profile of amorphous silica is consistent with calculated profiles with vertical pore-water flow. This flow is presently less than $1 \mathrm{~cm} / \mathrm{yr}$ (Shipboard Scientific Party, 1992e) but was probably quite vigorous in the past. The upwelling fluids must have been undersaturated with amorphous silica, because of the low concentrations of amorphous silica.

\section{CONCLUSIONS}

Drilling during Leg 139 provided us with a unique set of samples for which diagenesis of amorphous silica exists in a framework where several of the crucial parameters governing the rate of diagenesis vary from site to site. Based on analyses of samples from Leg 139 and their comparison to calculated profiles using a steady-state advection-diffusion-reaction model, we have shown that:

1. Precluding hydrothermal processes and associated high heat flow, pore waters maintain equilibrium with amorphous silica and the transition from amorphous silica to quartz requires well over 400 k.y. (e.g. Site 855).

2. Amorphous silica in areas with high heat flow undergoes transformation to quartz as concentrations of amorphous silica diminish to baseline levels. This transition requires only several hundred k.y. in Middle Valley. Based on the measured temperature gradients and profiles of dissolved and amorphous silica from Holes 857A, 857C, and $858 \mathrm{~A}$, this transition occurs in sediments with temperatures less than $100^{\circ} \mathrm{C}$, probably about $50^{\circ} \mathrm{C}$ for the change from amorphous silica to chalcedony and about $80^{\circ} \mathrm{C}$ for the change from chalcedony to quartz.

3. Pore-water flow greatly enhances dissolution of amorphous silica in Middle Valley. At 10 mbsf concentrations of amorphous silica can be less than $10 \%$ of the value near the sediment-water interface because of previous or existing vertical flow of pore water undersaturated with amorphous silica.

4. Profiles of dissolved silica serve as a good proxy for estimating depth intervals where amorphous silica is transformed into quartz.

5. Measurements of dissolved silica in squeezed samples are lower than in-situ values because of sampling artifacts that occur when insitu temperatures are above $50^{\circ} \mathrm{C}$.

The model we present in this paper provides a context for a better understanding of the diagenesis of amorphous silica in areas with high heat flow and complex patterns of pore-water flow. The two main ingredients lacking in the model are an ability to account for non-steady-state processes, which are extremely difficult to quantify in any context, and for the transition of amorphous silica to quartz. We are presently developing a model to address the temperature dependence of this transition.

\section{ACKNOWLEDGMENTS}

This research was supported by the Ocean Drilling Program and by a grant from the Joint Oceanographic Institutions U.S. Science Support Program. We would like to thank K. Dadey, E. Davis, and an anonymous reviewer for their thoughtful reviews of this manuscript. This is contribution number 3502 from the School of Ocean and Earth Science and Technology of the University of Hawaii.

\section{REFERENCES ${ }^{*}$}

Barnes, R.O., 1988. ODP in-situ fluid sampling and measurement: a new wireline tool. In Mascle, A., Moore, J.C., et al., Proc. ODP, Init. Repts., 110: College Station, TX (Ocean Drilling Program), 55-63.

Berner, R.A., 1978. Rate control of mineral dissolution under earth surface conditions. Am. J. Sci., 278:1235-1252.

Davis, E.E., and Villinger, H., 1992. Tectonic and thermal structure of the Middle Valley sedimented rift, northern Juan de Fuca Ridge. In Davis, E.E., Mottl, M.J., Fisher, A.T., et al., Proc. ODP, Init. Repts., 139: College Station, TX (Ocean Drilling Program), 9-41.

DeMaster, D.J., 1981. The supply and accumulation of silica in the marine environment. Geochim. Cosmochim. Acta, 45:1715-1732.

Fanning, K.A., and Pilson, M.E.Q., 1974. Diffusion of dissolved silica out of deep-sea sediments. J. Geophys. Res., 79:1293-1297.

Gieskes, J.M., and Peretsman, G., 1986. Water chemistry procedures aboard JOIDES Resolution-some comments. ODP Tech. Note, 5.

McDuff, R.E., 1985. The chemistry of interstitial waters, Deep Sea Drilling Project Leg 86. In Heath, G.R., Burckle, L.H., et al., Init. Repts. DSDP, 86: Washington (U.S. Govt. Printing Office), 675-687.

\footnotetext{
Abbreviations for names of organizations and publications in ODP reference lists follow the style given in Chemical Abstracts Service Source Index (published by American Chemical Society).
} 
Mortlock, R.A., and Froelich, P.N., 1989. A simple method for the rapid determination of biogenic opal in pelagic marine sediments. Deep-Sea Res. Part A, 36:1415-1426.

Schink, D.R., Guinasso, N.L., and Fanning, K.A., 1975. Processes affecting the concentration of silica at the sediment-water interface of the Atlantic Ocean. J. Geophys. Res., 80:3013-3031.

Shipboard Scientific Party, 1992a. Explanatory notes. In Davis, E.E., Mottl, M.J., Fisher, A.T., et al., Proc. ODP, Init. Repts., 139: College Station, TX (Ocean Drilling Program), 55-97.

1992b. Site 855. In Davis, E.E., Mottl, M.J., Fisher, A.T., et al., Proc. ODP, Init. Repts., 139: College Station, TX (Ocean Drilling Program), 101-160.

1992c. Site 856. In Davis, E.E., Mottl, M.J., Fisher, A.T., et al., Proc. ODP, Init. Repts., 139: College Station, TX (Ocean Drilling Program), 161-281.

1992d. Site 857. In Davis, E.E., Mottl, M.J., Fisher, A.T., et al., Proc. ODP, Init. Repts., 139: College Station, TX (Ocean Drilling Program), 283-429. 1992e. Site 858. In Davis, E.E., Mottl, M.J., Fisher, A.T., et al., Proc. ODP, Init. Repts., 139: College Station, TX (Ocean Drilling Program), 431-569.

Walther, J.V., and Helgeson, H.C., 1977. Calculations of the thermodynamic properties of aqueous silica and the solubility of quartz and its polymorphs at high pressures and temperatures. Am. J. Sci., 277:1315-1351.

Wheat, C.G., 1990. Fluid circulation and diagenesis in an off-axis hydrothermal system: the Mariana Mounds [Ph.D. dissert.]. Univ. of Washington, Seattle, WA.

Wheat, C.G., and Mottl, M.J., in press. Hydrothermal circulation, Juan de Fuca Eastern Flank: factors controlling basement water composition. J. Geophys. Res.

Date of initial receipt: 10 March 1993

Date of acceptance: 17 September 1993

Ms 139SR-225 